Copyright (C) 2017 by Academic Publishing House Researcher

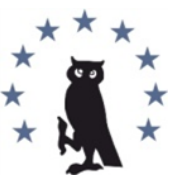

Published in the Russian Federation

European Researcher. Series A

Has been issued since 2010.

ISSN 2219-8229

E-ISSN 2224-0136

2017, 8(3): 245-255

DOI: $10.13187 /$ er.2017.3.245

www.erjournal.ru

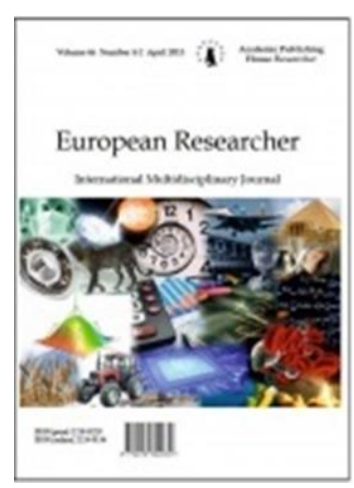

UDC 159.9

\title{
The Influence of Coaching Towards Therapeutic Communication Implementation
}

\author{
Beta Sugiarso $^{\text {a }}{ }^{*}$, Suryani $^{\text {a }}$, Titin Sutini ${ }^{\text {a }}$ \\ a Padjadjaran University, Bandung, Indonesia
}

\begin{abstract}
The problem of therapeutic communication implementation is the main issue that frequently happens in Indonesia nursing services. Education and training efforts in enhancing therapeutic communication implementation have been realized, however it did not get optimal result yet so that innovation is highly needed, especially coaching intervention. This research is to comprehend and analyze the influence of coaching towards therapeutic communication implementation. Research design utilizes semi-experiment with pre and post-test control group. Sampling method is by using Proportionate Stratified Random Sampling. The total of sample is 32 respondents comprising of 15 respondents from treatment group and 16 respondents from control group. Testing analysis using paired t test reveals that there is an effect of coaching toward therapeutic communication implementation on treatment group which means difference (75.32 and 26.62) higher than control group (18.81 and 11.44). Result of testing analysis using independent test shows the difference of therapeutic communication implementation on both groups. On pre-test, there is no mean difference, while on post-test, there is mean difference. Influence of coaching towards therapeutic communication implementation is there. It is suggested for hospital to use coaching in order to enhance therapeutic communication implementation.
\end{abstract}

Keywords: coaching, nursing, therapeutic communication.

\section{Introduction}

Therapeutic communication is the communication done by nurses and clients (Videbeck, 2011). Therapeutic communication is generally not implemented yet in accordance with procedures. The condition is one of problem phenomena that frequently happen in nursing (Brinkert, 2010; Chant et al., 2002). Therapeutic communication in nursing services is in a very low category (Oczkowski et al., 2016). There are about more than $80 \%$ nurses that only use three therapeutic communication techniques from seven basic techniques that actually should be done in nursing services (Koo et al., 2016).

The problem of nurses' therapeutic communication becomes the health world's attention. Some international institutions conduct researches regarding to nurses' communication and other health workers. The Health Complaint Information Program; Health Services Commissioner finds $31.6 \%$ of communication problem occurs in nurses and clients (Taylor et al., 2002). The Joint

\footnotetext{
${ }^{*}$ Corresponding author

E-mail addresses: betasugiarso@gmail.com (B. Sugiarso),

ynsuryani23@gmail.com (Suryani), titin.sutini20@yahoo.com (T. Sutini)
} 
Commission on Accreditation of Healthcare Organizations also finds almost $70 \%$ of dangerous incidents or service errors in hospital are related to communication (JCAHO, 2008 in WHO, 2009). Therapeutic communication problems are also found as much $51.7 \%$ in Malawian Hospitals (Madula, 2013) and as much $48 \%$ in Nottinghamshire, UK (Siyambalapitiya et al., 2007).

Therapeutic communication in Indonesia nursing services is not optimally implemented yet since there are still some nurses that do not implement this therapeutic communication yet. Therapeutic communication implementation in Salatiga hospital is only about $25 \%$ (Hendri, 2015), while in Palembang hospital is only about $29.7 \%$.Therapeutic communication, which is not in line with procedures, is highly related to nurses' personalities. Nurses are lack of appreciating therapeutic relationship and prioritizing jobs as well as being busier with other responsibilities than communicating with clients (McCabe, 2003).

Therapeutic communication can be enhanced by some improvement methods of nurses' personalities. The methods are such as through education and training (Tsai et al., 2013; Streeter, 2010), planning program of therapeutic communication (Younis et al, 2015), solution-focused communication training (Shermeh et al, 2013), small group, role play (Sullivan, 2011), teach-back method (Thinsan, 2015), and additional intervention based on clinical services, such as feedback from colleagues (Kim et al., 2008), health Coaching (Cinar, Schou, 2014), and simulation based on team work (Curtis, 2013; Kutzin, Jared, 2010).

Coaching is communication method in form of partnership between a coach and a coached to maximize self-potency. It is not education or training. It does not give material as in education or training. It is a process of exploring someone's ability through active listening and powerful questioning so that someone can find a solution and reach the expected outcome (ICF, 2015; Donner, Wheeler,2009). International Coaching Federation found that coaching is $38 \%$ beneficial for self development, $41 \%$ for interpersonal relationship enhancement, $26 \%$ for someone's communication skill improvement (ICF, 2012).

Based on the problem in therapeutic communication implementation and the significance of seeking right solution, then the researcher conducts a research with purpose to know whether coaching influential on nurses' therapeutic communication implementation in accordance with the standard of therapeutic communication.

\section{Methods}

This research's design is semi-experiment with pre and post test control group. The sampling is by using Proportionate Stratified Random Sampling. The total of sample is 26 respondents classified into twofold: 16 respondents from treatment group and 16 respondents from control group. The tests used in this research are paired and unpaired t test.

\section{Results}

3.1. Frequency distribution of respondents on treatment group and control group in Table 1.

The frequency distribution of respondents on treatment group and control group can be seen

Table 1. Frequency Distribution of Respondents on Treatment Group ( $n=16)$ and Control Group $(\mathrm{n}=16)$

\begin{tabular}{|c|c|c|c|c|c|c|c|}
\hline \multirow[t]{2}{*}{ Characteristics } & \multicolumn{2}{|c|}{$\begin{array}{c}\text { Treatment } \\
\text { group } \\
{[\mathrm{n}=16]}\end{array}$} & \multicolumn{2}{|c|}{$\begin{array}{l}\text { Control } \\
\text { Group } \\
{[n=16]}\end{array}$} & \multicolumn{2}{|c|}{ Total } & \multirow[t]{2}{*}{$P$ value } \\
\hline & $f$ & $\%$ & $\mathrm{f}$ & $\%$ & $f$ & $\%$ & \\
\hline $\begin{array}{l}\text { Age } \\
19-34 \text { years old } \\
35-60 \text { years old }\end{array}$ & $\begin{array}{l}13 \\
3\end{array}$ & $\begin{array}{l}81.2 \\
18.8\end{array}$ & $\begin{array}{l}9 \\
7\end{array}$ & $\begin{array}{l}56.2 \\
43.8\end{array}$ & $\begin{array}{l}22 \\
10\end{array}$ & $\begin{array}{l}68.8 \\
31.2\end{array}$ & 0.253 \\
\hline Gender & & & & & & & \\
\hline Male & 5 & 31.2 & 4 & 25.0 & 9 & 28.1 & 1.000 \\
\hline Female & 11 & 68.8 & 12 & 75.0 & 23 & 71.9 & \\
\hline Education & & & & & & & \\
\hline
\end{tabular}




\begin{tabular}{|c|c|c|c|c|c|c|c|}
\hline \multirow[t]{2}{*}{ Characteristics } & \multicolumn{2}{|c|}{$\begin{array}{l}\text { Treatment } \\
\text { group } \\
{[\mathrm{n}=16]}\end{array}$} & \multicolumn{2}{|c|}{$\begin{array}{l}\text { Control } \\
\text { Group } \\
{[n=16]}\end{array}$} & \multicolumn{2}{|c|}{ Total } & \multirow[t]{2}{*}{$P$ value } \\
\hline & $\mathrm{f}$ & $\%$ & $\mathrm{f}$ & $\%$ & $\mathrm{f}$ & $\%$ & \\
\hline $\begin{array}{l}\text { Age } \\
19-34 \text { years old } \\
35-60 \text { years old }\end{array}$ & $\begin{array}{l}13 \\
3\end{array}$ & $\begin{array}{l}81.2 \\
18.8\end{array}$ & $\begin{array}{l}9 \\
7\end{array}$ & $\begin{array}{l}56.2 \\
43.8\end{array}$ & $\begin{array}{l}22 \\
10\end{array}$ & $\begin{array}{l}68.8 \\
31.2\end{array}$ & 0.253 \\
\hline DIII & 13 & 81.2 & 13 & 81.2 & 26 & 81.2 & 1.000 \\
\hline Nurse Profession [Ners] & 3 & 18.8 & 3 & 18.8 & 6 & 18.8 & \\
\hline $\begin{array}{l}\text { Training } \\
\text { Once } \\
\text { Twice }\end{array}$ & $\begin{array}{l}15 \\
1 \\
\end{array}$ & $\begin{array}{l}93.8 \\
6.2\end{array}$ & $\begin{array}{l}15 \\
1\end{array}$ & $\begin{array}{l}93.8 \\
6.2\end{array}$ & $\begin{array}{l}30 \\
2\end{array}$ & $\begin{array}{l}93.8 \\
6.2\end{array}$ & 1.000 \\
\hline $\begin{array}{l}\text { Work Duration } \\
<2 \text { years } \\
\geq 2 \text { years }\end{array}$ & $\begin{array}{l}3 \\
13 \\
\end{array}$ & $\begin{array}{l}18.8 \\
81.2 \\
\end{array}$ & $\begin{array}{l}2 \\
14 \\
\end{array}$ & $\begin{array}{l}12.5 \\
87.5\end{array}$ & $\begin{array}{l}5 \\
27 \\
\end{array}$ & $\begin{array}{l}15.6 \\
84.4\end{array}$ & 1.000 \\
\hline Total & 16 & 100 & 16 & 100 & 32 & 100 & \\
\hline
\end{tabular}

3.2. Therapeutic communication implementation on treatment group and control group before intervention

Therapeutic communication implementation on treatment group and control group before intervention can be seen in Table 2.

Table 2. Therapeutic Communication Implementation on Treatment Group and Control Group before Intervention

\begin{tabular}{|c|c|c|c|c|}
\hline $\begin{array}{l}\text { Therapeutic Communication } \\
\text { Implementation }\end{array}$ & Group & Mean & $\mathrm{SD}$ & P Value \\
\hline \multirow{2}{*}{$\begin{array}{l}\text { Pre-Test } \\
\text { Instrument } 1 \\
\text { (interview and observation) }\end{array}$} & Treatment & 74.06 & 12.36 & \multirow{2}{*}{0.261} \\
\hline & Control & 78.38 & 8.60 & \\
\hline \multirow{2}{*}{$\begin{array}{l}\text { Pre-Test } \\
\text { Instrument } 2 \\
\text { (self assessment) }\end{array}$} & Treatment & 66.88 & 11.61 & \multirow{2}{*}{0.962} \\
\hline & Control & 67.06 & 10.32 & \\
\hline
\end{tabular}

3.3. Therapeutic communication implementation on treatment group and control group after intervention

Therapeutic communication implementation on treatment group and control group after intervention can be seen in Table 3 .

Table 3. Therapeutic communication implementation on treatment group and control group after intervention

\begin{tabular}{|c|c|c|c|c|}
\hline Therapeutic Communication Implementation & Group & Mean & $\mathrm{SD}$ & P Value \\
\hline \multirow{2}{*}{$\begin{array}{l}\text { Post-Test } \\
\text { Instrument } 1 \\
\text { (interview and observation) }\end{array}$} & Treatment & 149.38 & 13.24 & \multirow[b]{2}{*}{0.000} \\
\hline & Control & 97.19 & 11.33 & \\
\hline \multirow{2}{*}{$\begin{array}{l}\text { Post-Test } \\
\text { Instrument } 2 \\
\text { (self assessment) }\end{array}$} & Treatment & 93.50 & 6.58 & \multirow[t]{2}{*}{0.000} \\
\hline & Control & 78.50 & 7.40 & \\
\hline
\end{tabular}

3.4. Therapeutic communication implementation on treatment group before and after intervention 
Therapeutic communication implementation on treatment group before and after intervention can be seen in Table 4 .

Table 4. Paired $\mathrm{T}$ Test Result of Therapeutic Communication Implementation on Treatment Group before and after Intervention

\begin{tabular}{|c|c|c|c|c|c|}
\hline Therapeutic Communication Implementation & Phase & Mean & $\mathrm{SD}$ & Difference & P Value \\
\hline \multirow{2}{*}{$\begin{array}{l}\text { Instrument } 1 \\
\text { (interview and observation) }\end{array}$} & Pre-Test & 74.06 & 12.36 & \multirow{2}{*}{$75 \cdot 32$} & \multirow{2}{*}{0.000} \\
\hline & Post-Test & 149.38 & 13.34 & & \\
\hline \multirow{2}{*}{$\begin{array}{l}\text { Instrument } 2 \\
\text { (self assessment) }\end{array}$} & Pre-Test & 66.88 & 11.61 & \multirow{2}{*}{26.62} & \multirow{2}{*}{0.000} \\
\hline & Post-Test & 93.50 & 6.58 & & \\
\hline
\end{tabular}

3.5. Therapeutic communication implementation on control group before and after intervention

Therapeutic communication implementation on control group before and after intervention can be seen in Table 5 .

Table 5. Paired T Test Result of Therapeutic Communication Implementation on Control Group before and after Intervention

\begin{tabular}{|l|c|c|c|c|c|}
\hline \multicolumn{1}{|c|}{$\begin{array}{c}\text { Therapeutic Communication } \\
\text { Implementation }\end{array}$} & Phase & Mean & SD & Difference & P Value \\
\hline $\begin{array}{l}\text { Instrument 1 } \\
\text { (interview and observation) }\end{array}$ & Pre-Test & 78.38 & 8.60 & \multirow{2}{*}{8.81} & \multirow{2}{*}{0.000} \\
\cline { 2 - 6 } & Post-Test & 97.19 & 11.33 & 18.81 & \\
\hline \multirow{2}{*}{$\begin{array}{l}\text { Instrument 2 } \\
\text { (self assessment) }\end{array}$} & Pre-Test & 67.06 & 10.32 & \multirow{2}{*}{0.000} \\
\cline { 2 - 6 } & Post-Test & 78.50 & 7.40 & & \\
\hline
\end{tabular}

3.6. Mean Difference of therapeutic communication implementation on treatment group and control group before and after intervention

Mean difference of therapeutic communication implementation on treatment group and control group before and after intervention can be seen in Table 6 .

Table 6. Mean Difference of Therapeutic Communication Implementation on Treatment Group and Control Group before and after Intervention

\begin{tabular}{|c|c|c|c|c|c|c|}
\hline $\begin{array}{c}\text { Therapeutic } \\
\text { Communication } \\
\text { Implementation }\end{array}$ & $\begin{array}{l}\text { Instrument } \\
\text { Assessment }\end{array}$ & Group & Mean & SD & Difference & P Value \\
\hline \multirow{4}{*}{$\begin{array}{l}\text { Pre-Test } \\
\text { Before Intervention }\end{array}$} & \multirow{2}{*}{$\begin{array}{l}\text { Instrument } 1 \\
\text { (interview and } \\
\text { observation) }\end{array}$} & Treatment & 74.06 & 12.36 & \multirow[b]{2}{*}{$4 \cdot 32$} & \multirow{2}{*}{0.261} \\
\hline & & Control & 78.38 & 8.60 & & \\
\hline & \multirow{2}{*}{$\begin{array}{l}\text { Instrument } 2 \\
\text { (self assessment) }\end{array}$} & Treatment & 66.00 & 11.61 & \multirow{2}{*}{0.18} & \multirow{2}{*}{0.962} \\
\hline & & Control & 67.06 & 10.32 & & \\
\hline \multirow{4}{*}{$\begin{array}{l}\text { Post-Test } \\
\text { After Intervention }\end{array}$} & \multirow{2}{*}{$\begin{array}{l}\text { Instrument } 1 \\
\text { (interview and } \\
\text { observation) }\end{array}$} & Treatment & 149.38 & 13.24 & \multirow[b]{2}{*}{52.19} & \multirow[b]{2}{*}{0.000} \\
\hline & & Control & 97.19 & 11.33 & & \\
\hline & \multirow{2}{*}{$\begin{array}{l}\text { Instrument } 2 \\
\text { (self assessment) }\end{array}$} & Treatment & 93.50 & 6.58 & \multirow{2}{*}{15} & \multirow{2}{*}{0.000} \\
\hline & & Control & 78.50 & 7.40 & & \\
\hline
\end{tabular}


3.7. Distinction of mean difference of therapeutic communication implementation on treatment group and control group before and after intervention

Distinction of mean difference of therapeutic communication implementation on treatment group and control group before and after intervention can be seen in Table 7 .

Table 7. Distinction of Mean Difference of Therapeutic Communication Implementation on Treatment Group and Control Group before and after Intervention

\begin{tabular}{|l|l|l|l|l|l|}
\hline \multirow{2}{*}{ Therapeutic Communication Implementation } & Group & Mean & SD & $95 \%$ CI & $\begin{array}{l}\text { P } \\
\text { Value }\end{array}$ \\
\hline \multirow{2}{*}{ Difference of Instrument I } & & & & & \\
\cline { 2 - 5 } & Treatment & 75.31 & 15.13 & $47.45-65.55$ & \multirow{2}{*}{0.000} \\
\cline { 2 - 5 } Difference of Instrument II & Treatment & 26.63 & 10.92 & $9.13-21.24$ & \multirow{2}{*}{0.000} \\
\cline { 2 - 5 } & Control & 11.44 & 4.63 & $9.01-21.37$ & \\
\hline
\end{tabular}

\section{Discussion}

4.1. Therapeutic communication implementation on treatment group and control group before intervention

Research result on treatment group and control group before intervention reveals that therapeutic communication implementation is not optimal yet. The first instrument of Pre-test (interview and observation)on treatment group shows that therapeutic communication is in fair category (74.06) and control group is in fair category as well (78.38), meaning that therapeutic communication is implemented optimally, nurses sometimes implement and sometimes do not implement therapeutic communication optimally. The result of the first instrument of pre-test on both groups reveals that the mean difference is not there ( $p$ value $>0.05$ ).

The result of the second instrument of pre-test (self assessment) on treatment group shows that therapeutic communication is in normally category that is 66.88 and control group is also in normally category that is 67.06. It means that respondents assess themselves in the category of not optimal to implement therapeutic communication. It also reveals that both groups do not have mean differences ( $p$ value> 0.05). Therapeutic communication implementation on both groups before intervention does not reach optimal categories: excellent category that is $119-175$ and many times category that is $93-108$.

Pavlov Theory becomes the basis that the training that is only done once does not influence someone's attitude change (Pavlov, 1936 in Cambiaghi, Sacchetti, 2015). This is because learning process does not occur continuously. Therapeutic communication training that is only conducted on certain events and not continuous will reveal less optimal therapeutic communication implementation result. Behaviorism theory of Watson (1913) also states that someone needs learning because everyone, when born, does not bring any skills; everyone grows with stimulus received from circumstances (Watson, 1913).

Therapeutic communication implementation cannot run optimally if it is not equipped with continuous learning process. As the result of this research, the pre-test of both groups reveals low mean of therapeutic communication implementation. This condition is supported by the research of Kushnir, Ehrenfeld and Shalish (2008) proving that nurses' communication skills have low mean which is 3.61 if intervention is not implemented well which is 3.93. It is same as the research of Mehmet et al. (2011) revealing that nurses' communication skills have low value which is 177.8 if intervention is not conducted to improve implementation based on operational procedures which is 198.8 .

4.2. Therapeutic communication implementation on treatment group and control group after intervention

Therapeutic communication implementation on both groups after intervention shows mean difference compared to before intervention. The first instrument of post-test [interview and observation] reveals that treatment group is in excellence category which is 149.38 that means therapeutic communication is implemented well; respondents have implemented therapeutic 
communication in accordance with procedures. While, control group is in adequate category which is 97.19; meaning that therapeutic communication is implemented sufficiently but not very good yet. The result of the first instrument's post-test on both groups shows that mean differences are there ( $\mathrm{p}$ value< 0.05 ).

The research's result of therapeutic communication implementation on both groups after being given intervention reveals increase of mean although significant differences between posttest on treatment group and post-test on control group are also found. The increase of mean on treatment group is higher than control group. It is caused by coaching treatment given continuously for 3 meetings and supported by respondents' characteristics that are mostly in the period of young adults growth aged 19-34 years old.

Phase of young adult's growth is the part of eight phases of human ego's growth namely intimacy vs. isolation (Erickson, 1968 in Munley, 1977; Guelen, 1986).Young adults undergo improvement of experience, knowledge, self concept, motor skill, and duty focus (Potter, Perry, 2009). Besides, old adults nurses on respondents (31.2 \%) undergo skill development, have fast comprehension and skill, serve well, have sympathy, give attention and knowledge to young generation, be responsible and willing to always contribute (Erikson, 1964 in Karcher, Benne, 2007; Guelen, 1986).

Other characteristics influencing improvement of therapeutic communication implementation on both groups is gender, education level, and work duration. According to Varcarolis \& Halter (2011), gender is a significant factor in cooperation. Global Survey of Communications Measurement in 2009 states that education level influences $48 \%$ towards the success of therapeutic communication implementation (Wright et al., 2009). It is same as Roatib (2007) finding that nurses' work duration has correlation that symbolizes nurses' motivation in implementing therapeutic communication ( $\mathrm{p}$ value 0.034 ).

Therapeutic communication implementation on treatment group after getting coaching shows a significant improvement. The result of this research has similarity to the research of Kushnir, Ehrenfeld and Shalish (2008) proving that nurses' communication skill after getting coaching intervention increases to be 3.93 which is previously only 3.61. Furthermore, the research of Andreanoff (2016) also reveals that coaching can improve someone's skill significantly with posttest mean 4.72 compared to previous mean 3.98 .

4.3. Therapeutic communication implementation on treatment group before and after intervention

Based on result of statistics analysis, it shows that mean differences of therapeutic communication implementation on treatment group before and after intervention are there. Respondents on treatment group not only get common intervention in form of training, but they also get coaching. The research' result shows that the first instrument [interview and observation] with pre-test mean 74.06increases to be 149.38. The first instrument reveals a very significant improvement result with mean difference 75.32 ( $\mathrm{p}$ valueo.00o). The improvement of therapeutic communication implementation from fair category 9therapeutic communication implementation is in minimum level) increases to be excellence category (therapeutic communication implementation is implemented very well and is in line with the right procedure).

Coaching is a communication method that influences someone's change. It is about communication that focuses on clients (Donner, Wheeler, 2009). It is a form of partnership that maximizes self potency by exploring thoughts and creativities to obtain awareness and to identify ourselves (Natalie Ashdown in ICF, 2015). It can manage mentality and creativity of mind so that it causes attitude change (ICF, 2015; Gregory et al., 2011).

Coaching can influence change on some contexts. The research conducted by Brinkman et al. (2007) and Kleiner et al. (2014) prove that coaching can improve communication skills of nurses. It is in line with research of Grant (2013) revealing that coaching can enhance goal achievement, focus on solution, ability to change, and increase self confidence as well as leadership.

This influence happens because coaching can give external stimulus that can help someone's self change (ICF, 2015; Gregory et al., 2011). Intervention of coaching is mind exploration and creativity of respondents so that it gives better changes in therapeutic communication implementation. Coaching helps respondents in managing mentality and creativity of mind to always consistently implement therapeutic communication based on standard operational 
procedure. It gives respondents' awareness regarding to the significance of therapeutic communication as a way to achieve nursing and clients purposes under the care of nursing.

The researcher believes that significant coaching's influence towards therapeutic communication implementation is not only affected by continuous coaching intervention, but it is also affected by several characteristics and motivation of respondents to have better changes in giving professional nursing care. Coaching gives change stimulation of therapeutic communication implementation correctly and effectively. It can be made as a follow-up program besides therapeutic communication training or other competence trainings and as an innovative solution in nursing services. In contrast, the use of coaching in improving nurses' competence should be conducted consistently and continuously so that it can facilitate competence change in accordance with operational procedure.

4.4. Therapeutic communication implementation on control group before and after intervention

The research result on control group also reveals mean differences of therapeutic communication implementation although it only gets common intervention in form of therapeutic communication training only. The first instrument (interview and observation) shows that mean of pre-test 78.38 increases to post-test 97.19. It shows a lower result than treatment group with its mean difference is 18.81 ( $\mathrm{p}$ value 0.000). Therapeutic communication implementation from fair category (minimum therapeutic communication implementation) increases to be adequate category (therapeutic communication is conducted sufficiently but not very good yet).

The increase of therapeutic communication implementation on control group is also demonstrated on the second instrument measurement (self assessment) in which its pre-test means 67.06 increases to be 78.50. The second instrument shows a lower increase than treatment group with its mean difference is 11.44 ( $p$ value 0.000$]$. Therapeutic communication implementation from normally category [nurses assessing themselves still in "normal" category is not optimal yet) increases to be very often category (nurses assessing themselves in very often category), but it does not achieve many times category yet as on treatment group.

The increase of therapeutic communication implementation on control group which is lower than treatment group shows that intervention of therapeutic communication training is not strongly enough to change therapeutic communication implementation to be more optimal. The research conducted by Tanabe et al. (2012) states that intervention of coaching-based communication training continued with supervision and evaluation has bigger possibility in enhancing communication than training intervention only ( $\mathrm{p}$ value 0.001 ) and control group ( $\mathrm{p}$ value 0.05).Even so, the research of Khodadadi, et al. (2013) also proves that communication training only can influence the improvement of nurses' communication skills ( $p$ value 0.008 ).

4.5. Mean difference of therapeutic communication implementation on treatment group and control group before and after intervention

Based on statistics analysis, it shows that mean difference between pre-test and post-test of therapeutic communication implementation on both group before and after intervention is there. Both groups before intervention have $\mathrm{p}$ value higher than 0.05 , then mean value of therapeutic communication implementation before intervention does not have significant difference. It is different from the result of post-test from both groups after intervention; both have $\mathrm{p}$ value lower than 0.05 then mean value of therapeutic communication implementation before intervention has significant difference.

Analysis result of mean difference on both groups before and after intervention has meaningful distinction. Distinction of mean difference on treatment group and control group before intervention with the first instrument measurement [interview and observation] is 4.32andthe second instrument (self assessment) is 0.18. This mean difference shows that both groups do not have significant difference ( $p$ value 0.261 and 0.962). Different from mean difference of both groups after intervention, the first instrument (interview and observation) has difference as much 52.19and the second instrument (self assessment) has difference as much 15. This mean difference shows that both groups after intervention have significant difference ( $p$ value o.00o).The analysis result of independent $t$ test regarding to mean difference of therapeutic communication implementation on both groups before and after intervention is $\mathrm{p}$ value $<0.05$. 
This result shows a difference on treatment group and control group both in the first instrument and in the second instrument.

The analysis result on treatment group and control group before and after intervention of coaching reveals mean score difference. Mean score on treatment group and control group after getting intervention increases; however both groups have a quite high mean score difference. The difference shows that coaching intervention on treatment group is more significant to improve therapeutic communication implementation than on control group which gets training only.

Coaching is stimulation and exploration of creative minds to dig thoughts and make respondents' self learning process through partnership to maximize potency (ICF, 2015). It does not give suggestion, does not teach or direct, but it is a collaborative relationship to enhance performance and improve learning process as well as to assist clients in obtaining new skills (Parsloe, Wray, 2000 in Ekim, 2015; Dossey, Hess, 2013). It is different from training which is the method to improve skills and abilities through information and knowledge given by trainer.

Coaching is the method that influences psychology and physiology in assisting someone to find awareness area so that he or she obtains creative idea, help them to control attitude, and achieve their expected goals. It can dig potency from awareness area so that someone is aware of his/her skills (ICF, 2015; Freud in Irawan, 2015). Moreover, it can influence physiological change through change of human perception, mind, feeling, impulse, and action sent from central nerve system. Brain activity is the main mediator of body organ in controlling and determining human interaction (Fortinash, Worret, 2011). In the context of therapeutic communication implementation, coaching can change nurses' attitude to have a more optimal communication with strong stimulus from their own mind.

The research result of the coaching influence towards therapeutic communication implementation is in line with the research result conducted by Kushnir et al. (2008) revealing that there is a significant improvement after using coaching in motivation training, self-efficacy, and attitude change regarding to communication. It is also same as the research of Shields, et al (2010) proving that coaching intervention can improve someone's communication skills to express his/her feeling.

Research of coaching's influence towards therapeutic communication implementation is the research that contains renewal element. It is due to the fact that the present research is rarely conducted in nursing specifically on nurses' competence. This research also employs direct coaching, has a very short time but gives significant positive effects, and uses two measurement instruments which are observation and self assessment. The weakness of this research is it uses small sample although the research of Grant (2003) also uses small sample which is 20 respondents without having control group; and the research of Crowfoot et al. (2010) comprises of 15 respondents in the first group and 15 respondents in the second group.

\section{Conclusion and Suggestion}

\subsection{Conclusion}

This research examines influence of coaching towards therapeutic communication implementation. It uses semi-experiment method, pre and post test with control group, and 32 respondents divided to treatment group and control group. The result of this research proves that coaching influences more effectively on therapeutic communication implementation than routine intervention of therapeutic communication training. The analysis of both group before and after intervention of coaching reveals mean score difference. Both groups obtain improvement of therapeutic communication implementation, but meaningful difference is also there proving that coaching intervention on treatment group is more effective to enhance nurses' therapeutic communication implementation than on control group that only gets therapeutic communication training. Coaching can significantly influence on therapeutic communication implementation since it gives external stimulus that can have better changes in therapeutic communication implementation. Coaching gives awareness of mentality, mind, and creativity so that nurses have commitment to implement therapeutic communication. Coaching as the follow-up program of therapeutic communication training program can be an innovative solution in nursing. 


\subsection{Suggestion}

Coaching is expected to be continuously developed as basic competence of nursing since it is an effective and applicative method that explores nurses' potency and creativity in order to improve therapeutic communication implementation.

\section{References}

Andreanoff, 2016 - Andreanoff, $J$. (2016). Issues in conducting quantitative studies on the impact of coaching and mentoring in Higher Education. International Journal of Evidence Based Coaching and Mentoring, 10, 202.

Brinkert, 2010 - Brinkert, R. A. (2010). A literature review of conflict communication causes, costs, benefits and interventions in nursing. Journal of Nursing Management, 18(2), 145-156.

Brinkman et. al., 2007 - Brinkman, W. B., Geraghty, S. R., Lanphear, B. P., Khoury, J. C., Gonzales del Rey, J. A., Dewitt, T. G., et al. (2007). Effect of multisource feedback on resident communication skills and professionalism: a randomized controlled trial. Archives of Pediatrics \& Adolescent Medicine, 161(1), 44-49.

Cambiaghi, Sacchetti, 2015 - Cambiaghi, M., Sacchetti, B. (2015). Ivan Petrovich Pavlov (1849-1936). Journal of Neurology, 1599-1600.

Cinar, Schou, 2014 - Cinar, A. B., Schou, L. (2014). Interrelation between Patient Satisfaction and Patient-Provider Communication in Diabetes Management. The Scientific World Journal.

Croffoot et. al., 2010 - Croffoot, C., Bray, K. K., Black, M. A., Koerber, A. (2010). Evaluating the Effects of Coaching to Improve Motivational Interviewing Skills of Dental Hygiene Students. Journal of Dental Hygiene.

Curtis et. al., 2013 - Curtis, J. R., Back, A. L., Ford, D. W., Downey, L., Shannon, S. E., Doorenbos, A. Z., et al. (2013). Effect of Communication Skills Training for Residents and Nurse Practitioners on Quality of Communication With Patients With Serious Illness A Randomized Trial. Journal American Medical Association.

Donner, Wheeler, 2009 - Donner, G., Wheeler, M. M. (2009). Coaching in nursing: An Introduction. Geneva, Switzerland: International Council of Nurses.

Dossey, Hess, 2013 - Dossey, B. M., Hess, D. R. (2013). Professional nurse coaching: Advances in national and global healthcare transformation. Global Advances in Health and Medicine, 2(4), 10-16.

Ekim, 2015 - Ekim, A. (2015). A growing trend in pediatric nursing: Coaching. Jacobs Journal of Nursing and Care, 1(2), 6.

Fortinash, Worret, 2012 - Fortinash, K., Worret, P. H. (2012). Psychiatric mental health nursing. $5^{\text {th }}$ ed. USA: Elsevier.

Grant, 2013 - Grant, A. M. (2013). The Efficacy of Executive Coaching in Times of Organisational Change. Journal of Change Management, 14(2), 258-288.

Gregory et. al., 2011 - Gregory, J. B., Beck, J. W., \& Carr, A. E. (2011). Goals, feedback, and self-regulation: Control theory as a natural framework for executive coaching. Consulting Psychology Journal, 63(1), 26.

Guelen, 1986 - Guelen, D. (1986). The conditions of human development implications of socialization research for developmental theory. Theory Building in Developmental Psychology. North-Holland: Elsevier Science Publishers.

Hendri, 2007 - Hendri, A. (2007). Hubungan tingkat komunikasi terapeutik perawat dengan perilaku kooperatif anak usia pra sekolah yang mengalami hospitalisasi di bangsal anggrek RSUD Kota Salatiga. Stikes Kusuma Husada Surakarta.

ICF, 2012 - ICF. (2012). Global Coaching Study. Final Report.

ICF, 2015 - ICF. (2015). Profesional coach program icf acsth - 88 hours.Module 1 and 2. Indonesia: Loop.

Irawan et. al., 2015 - Irawan, A. G., Yulia, S., Apriany, A. (2015). Hubungan antara komunikasi perawat dengan kepuasan pasien terhadap pelayanan keperawatan di irna rumah sakit Muhammadiyah palembang. Seminar Nasional Forum Dosen Indonesia.

Karcher, Benne, 2007 - Karcher, M. J., \& Benne, B. (2007). Erik and joaneriksons' approach to human development in counseling. Chapter Seven. 
Khodadadi et.al., 2013 - Khodadadi, E., Ebrahimi, H., Moghaddasian, S., Babapour, J. (2013). The effect of communication skills training on quality of care, self efficacy, job satisfaction, and communication skills rate of nurses in hospitals of Tabriz, Iran. Journal of Caring Sciences, 2(1), 27-37.

Kim et. al., 2008 - Kim, Y. M., Heerey, M., Kols, A. (2008). Factors that enable nursepatient communication in a family planning context: A positive deviance study. International Journal of Nursing Studies, 45, 1411-1421.

Kleiner et. al., 2014 - Kleiner, C., Link, T., Maynard, M. T., Carpenter, H. K. (2014). Coaching to Improve the Quality of Communication during Briefings and Debriefings. AORN Journal, 100(4), 358-368.

Koo et. al., 2016 - Koo, L. W., Horowitz, A. M., Radice, S. D., Wang, M. Q., Kleinman, D. V. (2016). Nurse Practitioners' Use of Communication Techniques: Results of a Maryland Oral Health Literacy Survey. PLOS ONE.

Kushnir et al., 2008 - Kushnir, Ehrenfeld, Shalish (2008). The effects of a coaching project in nursing on the coaches'training motivation, training outcomes, and job performance: An experimental study. International Journal of Nursing Studies, 45, 837-845.

Kutzin, Jared, 2010 - Kutzin, Z. M., Jared, M. (2010). Communication and Teamwork Focused Simulation-Based Education for Nursing Students. Doctor of Nursing Practice (DNP) Capstone Projects.

Madula, 2013 - Madula, $P$. (2013). Nursing education and its impact on patient-healthcare provider communication in Malawian hospitals. Journal of Media and Communication Studies, 5(8), 123-131.

McCabe, 2003 - McCabe, C. (2003). Nurse-patient communication: an exploration of patients' experiences. Journal of Clinical Nursing, 13, 41-49.

Mehmet et. al., 2011 - Mehmet, A. K., Cinar, O., Sutcigil, L., Congologlu, E. D., Haciomeroglu, B., Canbaz, H. et al. (2011). Communication Skills Training For Emergency Nurses. International Journal of Medical Sciences, 8(5), 397-401.

Munley, 1977 - Munley, P. H. (1977). Erikson's Theory of Psychosocial Development and Career Development. Journal of Vocational Behavior, 10, 261-269.

Oczkowski et. al., 2016 - Oczkowski, S. J., Chung, H. O., Hanvey, L., Mbuagbaw, L., You, J. J. (2016). Communication Tools for End-of-Life Decision-Making in Ambulatory Care Settings: A Systematic Review and Meta-Analysis. PLOS ONE, 11(4).

Potter, Perry, 2009 - Potter, P. A., Perry, A. G. (2009). AG. Fundamental keperawatan. 7th ed. Translated by dr. Adrina Ferderika. Jakarta: Salemba Medika.

Roatib et. al., 2007 - Roatib, A., Suhartini, Supriyadi (2007). Hubungan Antara Karakteristik Perawatdengan Motivasi Perawat Pelaksana dalam Menerapkan Komunikasi Terapeutik Pada Fase Kerja Di Rumah Sakit Islam Sultan Agung Semarang. Thesis. Semarang, Indonesia: Department of Nursery, UNDIP.

Shermeh et. al., 2013 - Shermeh, S., Amiri, H., Karimi, Z. A., Bahari, F., Binesh, A. (2013). Effectiveness of Solution-Focused Communication Training [SFCT] in Nurses' Communication Skills. Iranian Journal of Military Medicine, 14(4), 279-286.

Shields et. al., 2010 - Shields, C. G., Ziner, K. W., Bourff, S. A., Schilling, K., Zhao, Q., Monahan, $P$., et al. (2010). An intervention to improve communication between breast cancer survivors and their physicians. $J$ Psychosoc Oncol, 28(6), 610-629.

Siyambalapitiya et. al., 2007 - Siyambalapitiya, S., Caunt, J., Harrison, N., White, L., Weremczuk, D., \& Fernando, D. J. (2007). A 22 month study of patient complaints at a National Health Service hospital. International Journal of Nursing Practice, 13, 107-110.

Streeter, 2010 - Streeter, A. C. (2010). What nurses say: communication behaviors associated with the competent nursing handoff. Doctoral Dissertation. University of Kentucky.

Sullivan et. al., 2011 - Sullivan, M., Ferguson, W., Sullivan, K., Haley, H. L., Philbin, M., Kedian, T., et al. (2011). Expert Communication Training for Providers in Community Health Centers. Journal of Health Care for the Poor and Underserved, 22, 1358-1368.

Tanabe et. al., 2012 - Tanabe, M., Suzukamo, Y., Tsuji, I., \& Izumi, S. (2012). Communication training improves sense of performance expectancy of public health nurses engaged in long-term elderly prevention care program. International Scholarly Research Network. 
Taylor et. al., 2002 - Taylor, D. M., Wolfe, R., \& Cameron, P. A. (2002). Complaints from emergency department patients largely result from treatment and communication problems. Emergency Medicine, 14, 43-49.

Thinsan, 2015 - Thinsan, S. (2015). Improving nurse-patient communication about new medicines. Master's Projects Paper 171. University of San Francisco, School of Nursing and Health Professions.

Tsai et. al., 2013 - Tsai, H. H., Tsai, Y. F., Weng, L. C., \& Chou, H. F. (2013). More than communication skills: experiences of communication conflict in nursing home nurses. Medical Education, 47, 990-1000.

Vacarolis, Halter, 2010 - Vacarolis, E., \& Halter, M. (2010). Foundation of psychiatric mental health nursing: A clinical approach. 6th ed. Canada: Saunders Elsevier.

Videbeck, 2011 - Videbeck, S. L. (2011). Psychiatric-mental health nursing 6th ed. China: Wolters Kluwer.

Watson, 1913 - Watson, J. B. (1913). Psychology as the Behaviorist Views it John B. Watson (1913). Classics in the History of Psychology An internet resource developed by Christopher D. Toronto, Ontario: Green York University.

WHO, 2009 - WHO (2009). Human Factors in Patient Safety Review of Topics and Tools ; Report for Methods and Measures Working Group of WHO Patient Safety. World Health Organization.

Wright et. al., 2009 - Wright, D. K., Gaunt, R., Leggetter, B., Daniels, M., Zerfass, A. (2009). Global Survey of Communications Measurement. Final Report. Association for Measurement and Evaluation of Communication (AMEC).

Younis et. al., 2015 - Younis, J. K., Mabrouk, S. M., Kamal, F. F. (2015). Kamal FF. Effect Of The Planned Therapeutic Communication Program On Therapeutic Communication Skills Of Pediatric Nurses. Journal of Nursing Education and Practice, 5(8). 